\title{
A Strong Start-up Scene Flourishes in the Life Sciences Capital Basel
}

\author{
Peter Burckhardt*
}

\begin{abstract}
Basel is known for its successful global players in Pharma, Agro and Chemicals. The wealth of top-tier companies, universities and academic institutions in such a small region is unparalleled. It creates an optimum climate for world-class research and its translation into successful businesses. This is also reflected in a strong start-up scene. Over the past decades the multinational players have shown that they are able to adapt to the ever-increasing challenges in the market. Basel has seen blue-chip company mergers, accompanied by the transfer of business assets into spin-off companies. This process created a mind-set for change which has positively influenced the local start-up environment. Actelion is one of these former spin-offs that successfully made the transition to become a global player. BioVersys and PIQUR are two of the most promising very early stage Swiss biotech companies. Many other examples can be found in Northwestern Switzerland. The region also offers a solid background of supporting activities. Infrastructure, coaching and all other support are offered and complement national innovation initiatives.
\end{abstract}

Keywords: Basel · Coaching · Incubator · Life Sciences start-up · Spin-off

Switzerland ranked first in the INSEAD Global Innovation Index 2012 for the development of innovative technologies, and Northwestern Switzerland represents particularly fertile soil for life sciences. Scientists working in the pharmaceutical and chemical industries in and around Basel and academics contribute equally to the combined state-of-the-art knowledge in chemistry and biology, which is a unique competitive advantage of the Basel area. Several thousand scientists with a higher academic degree work in life sciences research, development and production, supported by several tens of thousands of highly skilled technical and laboratory staff. The greater Basel area has close to 200 academic and public institutions with over 400 research groups. It is one of the leading international life sciences clusters, and represents one of the highest concentrations of life science resources in Europe. This also makes it particularly attractive for start-ups in this sector.

${ }^{\star}$ Correspondence: Dr. P. Burckhard

CEO EVA - the Basel life sciences start-up agency CEO BASEL INKUBATOR

President Biovalley Business Angels Club BioBAC Hochbergerstrasse 60C

$\mathrm{CH}-4057$ Basel, Switzerland

Tel.: +41612838485

Mobile: +41792164022

E-mail: pburckhardt@eva-basel.ch

\section{Successful Life Sciences Businesses in and around Basel}

In the pharmaceutical sector the blue chip giants Roche and Novartis have their global headquarters in Basel, and Bayer Consumer Care has its European headquarters there. Just a stone's throw away in Allschwil BL are the Actelion headquarters. The headquarters of Syngenta, a world agribusiness leader, are in the town center right next to the headquarters of the Swiss branch of BASF. The medtech sector is also well represented, with the headquarters of Straumann and Medartis.
On the outskirts of Basel, mainly upstream along the river Rhine into the neighboring canton Aargau and on the German Rhine board, there is a high density of production and research facilities.

All these companies provide jobs directly for their own staff, and indirectly for the employees of the many thousands of service and supply providers for both the businesses and their employees' families. The per-capita value added of the Northwestern Switzerland economic region is well in excess of the Swiss average.

For life sciences start-ups it is more than economic power that matters with

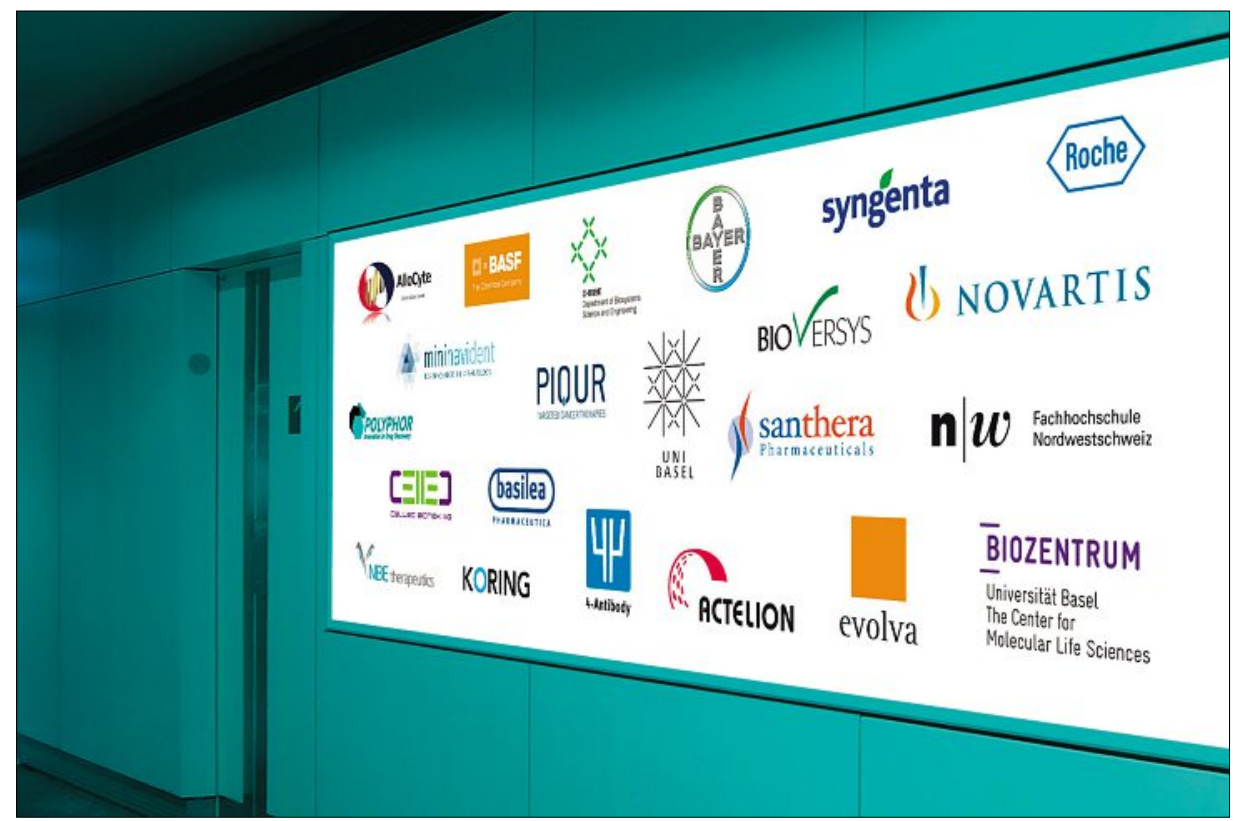

Framework for success: Basel area Life Sciences start-ups, blue chips and academia are always near potential partners. 
regards to established and successful companies. What matters is the presence of experienced professionals and access to experts who can provide consulting services as scientific or business advisors. Spin-offs prefer to stay near their universities and profit from the proximity of colleagues and experts. Marc Gitzinger, one of the founders of BioVersys, confirms that one of the main reasons for setting up the company in Basel was the opportunity for easy contact to life sciences experts within walking distance. Having lots of smart people around from the onset, all with an international outlook due to the small local market, increases the chances of success for budding entrepreneurs. And there are many of them in the Basel region, not only in the local industry, but also in academia.

\section{Academic Environment in Northwestern Switzerland}

Basel University, founded in 1460, is Switzerland's oldest university with a long humanistic, medical and scientific tradition. It has generated some remarkable medical and scientific alumni over the past centuries. Many of them today are founders of successful start-ups.

At the time of its opening in 1971, the Biocenter of Basel University (Biozentrum Basel) was the only one of its kind in Europe. The innovation was marked by its interdisciplinary approach to finding solutions to health problems through biological research as well as the need to establish a cutting-edge education for medical and biology students.

The DBSSE, the Department of Biosystems Science and Engineering that opened in 2007, is one of the ETH Zurich's youngest departments and the only one located in Basel outside of the Zurich campus. Both academic institutions attract many talented young life sciences students. At Basel University Hospital, a huge community of (future) medical professionals is striving to improve patients' health.

The University of Applied Sciences and Arts Northwestern Switzerland FHNW also contributes to basic academic education. Both Basel University and the FHNW are also actively engaged in fostering the regional start-up scene.

The Friedrich Miescher Institute funded to a large degree by Novartis - and the Swiss Tropical and Public Health institute are two more important players in life sciences academia.

\section{Successful Start-ups in Basel}

Regional start-ups that survived the many challenges of the first phases and today are publicly listed include Actelion, which today operates globally, funded mainly by the blockbuster drug Tracleer used in the treatment of pulmonary arterial hypertension.

Speedel licensed the first renin inhibitor at the time from Novartis in 1999, and licensed it back to Novartis for further development and marketing in 2002. Novartis fully acquired Speedel in 2008.

Santhera is headquartered in Liestal, Baselland, and focuses on the treatment of mitochondrial and neuromuscular diseases. The company was formed in August 2004 through the merger of the local life science start-up MyoContract AG with the German Graffinity Pharmaceuticals AG. The recent announcement of positive pivotal phase III clinical trial results, and the expectation of potential peak sales of CHF 560 million in the EU and North America significantly increased the value of Santhera shares. Santhera is an example of the need for tenacity and endurance despite experiencing the 'alternating bath' of frequent swings in fortune which are common for many start-ups. Having fought for survival in 2013, Santhera's share value sky-rocketed in summer 2014 after positive phase III clinical study results for its Raxone investigational drug for the treatment of Duchenne muscular dystrophy and Leber's Hereditary Optic Neuropathy (LHON). The prognosis is for blockbuster sales once market approval has been awarded, which is expected in 2015.

Basilea Pharmaceuticals was founded in 2000 and went public on the SIX Swiss Exchange in 2004. It focuses on the development of antibiotics, antifungals and oncology drugs for the treatment of drugresistant bacterial infections, systemic fungal infections and drug-resistant tumors. Through a global agreement with Stiefel, a GSK company, Basilea has been marketing one drug since June 2012, and has several clinical and pre-clinical compounds in different development phases.

Evolva was founded in 2004 and merged with Arpida in 2009. The company mainly provides ingredients and technologies for making ingredients to other companies in the food and beverage, consumer health and pharmaceutical sectors. Marketed products include stevia, vanilla, saffron and resveratrol. In what the company calls a parallel strategy to pursue options to partner its pharmaceutical pipeline, Evolva recently entered into a several million CHF contract with the US Defense Threat Reduction Agency (DTRA) for a program to develop the first oral antibiotic for the treatment of acute melioidosis and select agents.

Other local and successful start-ups include Bachem, a specialist in peptide synthesis that started off as Bachem
Feinchemikalien AG in 1971 with two employees in Liestal near Basel. It celebrated 40 years as a producer of research ingredients and active pharmaceutical ingredients for the pharmaceutical industry in 2011 with a headcount of almost 700 employees. Polyphor, headquartered in Allschwil, BL, and employing around 100 highly qualified staff, focuses on the discovery and development of macrocycle drugs.

\section{A Wealth of Support for Start-ups}

Life sciences entrepreneurs face particularly high and non-controllable risks during the entire path of product development. Nature and biology can strike in unforeseeable ways. Even the global pharmaceutical giants may get caught out by unpleasant surprises in the late stages of product development, such as unfavorable side effects or lack of efficacy of new medical products. This explains why life sciences start-ups are often nurtured within well-regarded institutions and through targeted support.

The BioValley initiative, founded in 1996 as a tri-national life-sciences network across Alsace in France, South Baden in Germany and Northwestern Switzerland, was the first to foster the creation of biotech start-ups and technology transfer. A group of visionary entrepreneurs and academics, among them Georg Endress, Fritz Bühler and Beat Löffler, wanted to turn the area into the most attractive European biotech region for new investments.

Today there are several other institutions supporting start-ups with coaching, consultancy, seed money and/or affordable infrastructure:

The branch of the Centre Suisse d'Electronique et de Microtechnique SA (CSEM) in Muttenz BL is a private, nonprofit Swiss company for applied research. Its vision is to enhance the competitiveness of Swiss micro- and nanotechnologies by developing applied technology platforms for a variety of markets and transferring them to the industrial sector. The CSEM has very close links to and is partially owned by the EPFL (Swiss Federal Institute of Technology, Lausanne), and is supported by the Swiss Confederation and several cantons.

i-net is a public-private partnership between the cantons of Baselland, BaselStadt, Jura and companies from the region. The network supports start-ups in ICT, life sciences, medtech, cleantech and nanotechnology with opportunities to network at various events.

In addition to contacts for developing, discussing and nurturing ideas, new entrepreneurs will soon also need space to mature their business idea in the physical 
sense. However, office space in or close to the Basel town center is rare and very expensive. This applies even more to laboratory space and equipment. But start-ups want and need to be close to academic institutions and life sciences industries.

A variety of business and technology parks for companies in different stages are operating in Northwestern Switzerland.

The business park in Reinach, one of the villages closest to the Basel agglomeration, rents offices and shared services. The Witterswil TZW Technology Center, also located close to Basel, where the canton Solothurn extends into the surrounding canton of Baselland, offers modern, flexible and adaptable space for start-ups and established SMEs, suitable for laboratories, offices and production facilities.

The concept for a new Swiss Innovation Park in Northwestern Switzerland for Biomedical Engineering, Sciences and Technologies, put forward in summer 2013, has been approved by the cantons Basel-Stadt and Baselland, and plans for setting it up on the border of Basel and Allschwil, close to the Actelion headquarters and branches of several established life sciences companies are currently being implemented.

The Technologiepark Basel, set up in 2011 in the Stücki Business Center in Basel, offers start-ups a mix of office, laboratory and meeting space at favorable conditions. The Stücki Business Center is also home and the global headquarters of Medartis, which produces medical devices for orthopedic surgery. The BASEL INKUBATOR and EVA, the Basel life sciences start-up agency, are also located in this building.

\section{Bridging Research, Business Ideas and Markets}

EVA - the Basel life sciences start-up agency, a limited company, founded in 1996 by the Cantonal Banks of Basel-Stadt and Baselland as major shareholders and visionary entrepreneurs, took a pioneering role in fostering life sciences start-ups in Northwestern Switzerland. EVA helps innovative life sciences start-ups on the way to their launch as a coaching partner. The first contact is usually established in a very early phase, by acting as sparring partner. EVA offers coaching and a network of experienced and highly regarded experts to shape young companies.

Entrepreneurs' project ideas are reviewed with regards to their degree of innovation, and clarity, feasibility and applicability of goals and objectives. EVA also supports market research and competitive analysis, patent analysis and application. Entrepreneurs get help with their business plans through plausibility, structure and content checks (with a special focus on the financial aspects), and with partnering and licensing contracts in later stages. The EVA Board of Directors and the EVA network bring together experts with a profound knowledge of the life sciences and finance. For start-ups EVA chooses to support, this well-established network can also be a source of highly professional board members. To date, EVA has supported 32 start-ups; 19 are still operational, and 11 are still in the Portfolio.

Next to supporting the financial planning and formal establishment of new life sciences companies, and thanks to the ongoing support of the cantonal banks of Basel-Stadt and Baselland, EVA can provide start-up financing and seed capital for the first phase, usually including a stake in share capital or subordinate convertible loans or long-term credits. Repayment terms carefully match the companies' business conditions. In contrast to almost all other seed money providers, EVA is an active investor and delegates active members to the companies' boards of directors.

However, EVA is neither a classical investment fund, nor a venture capitalist. The agency actively supports the search for further investors, and establishes contact with investors. EVA has close ties to the network of investors in the BioBAC BioValley Business Angels Club, and regularly links those investors with audited projects. This guarantees that Business Angels looks at verifiably good, implementable business ideas. BioBAC is the only Business Angels Club in Switzerland that focuses on life sciences companies. Since 2007 its members have invested more than $\mathrm{CHF}$ 50 million in over 20 start-ups. As financing opportunities for life science start-ups have eroded, with venture capital investment down $21 \%$ in $2012-13$ to its lowest level in more than a decade, private investments from Business Angels are crucial to fill the gap. For the first round of funding, life-sciences-oriented high-tech companies require between $\mathrm{CHF} 1$ and $\mathrm{CHF} 3$ million, and typically 3 to 10 investors to achieve this.

Since 2010 EVA also has the mandate to run the BASEL INKUBATOR, a joint venture between Basel University, the FHNW, the Canton BS, and EVA, to provide an affordable office and lab space infrastructure and coaching for high-tech University and FHNW start-ups. Young entrepreneurs in the BASEL INKUBATOR profit from highly favorable conditions for the first three years. Thanks to co-location with EVA, entrepreneurs from life sciences and related industrial sectors, such as informatics, computing, etc. get easy access to professional coaching and guidance.

\section{Conclusion}

Advancing young entrepreneurs by supporting them and their businesses promotes innovation effectively. For life sciences, support means huge financial investments as without sufficient funding over long periods of time the creativity and spontaneity of young, courageous and innovative entrepreneurs will soon be extinguished by the constraints of a hard market environment, and the fight for resources. However, successful life sciences startup support means more than just providing money. Without access to 'old hands' with specific expertise who feel motivated to coach and advise young entrepreneurs, their start-ups will likely fail due to too many mistakes made. In the Basel area entrepreneurs find an unparalleled combination of a very high concentration of commercially highly successful big players, and several start-ups who have managed to overcome the difficulties of the early phases. They also find a high density of academic institutions whose alumni provide human resources with top qualifications, and targeted support of selected, promising start-ups.

Received: October 10, 2014 